\title{
TECHNICAL TAKT PLANNING AND TAKT CONTROL IN CONSTRUCTION
}

\author{
Marco Binninger ${ }^{1}$, Janosch Dlouhy ${ }^{2}$ and Shervin Haghsheno ${ }^{3}$
}

\begin{abstract}
This paper is the counterpart to the paper Collaborative Takt Time Planning of Non-Repetitive Work of Iris Tommelein. Both paper describe Takt approaches in two different geographical and project contexts. A follow up paper is planned and will compare the described approaches and assesses their applicability and success.

This Paper describes the German Takt approach, called Technical Takt Planning and Takt Control. The authors used this method in on several projects in construction. It describes the historically development of Takt in construction in German and leads to the current state of the theoretical method used at the Karlsruhe Institute of Technology (KIT). The third part of the paper gives a practical example of the KIT approach.

The contribution of this paper is that it offers a characterization of the Takt approach that is used in Germany in several construction projects. The researchers try to give with the KIT Method an overview in science for the German Takt Planning and Takt Control approach. The method is for Takt integration in make to order production.
\end{abstract}

Keywords: Lean Construction, Production System, Takt Planning and Takt Control.

\section{INTRODUCTION}

Takt time is increasingly being used to structure construction work and thus "shape" project schedules. In the companion papers (Tommelein 2017) we refer to previous uses of Takt in production and offer a framework for characterization of Takt methods currently used in construction.

In German the word "Takt" means "beat" (Haghsheno et al. 2016) or the regularity with which something gets done. When the word is used in a Lean context, it is a concept interlinked with standardization, predictability, and many other Lean concepts. Takt refers to the heartbeat of assembly lines in the Toyota Production System (Haghsheno et al. 2016). Once a beat is set, every line can move in sync with others in a continuous flow process.

Whether at Toyota, more generally in product development and manufacturing, or in construction, Takt defines the unit of time within which a unit of production must be produced (supply rate) in order to match the rate at which that product is needed by the customer (demand rate). Takt Time is a design parameter used in a production setting, be it manufacturing, construction, or other any other setting.

The approaches used in different parts of the world and conceptualizations of Takt Time - even when applied in the same geographic region - appear to differ from one another. The aim of our ongoing study is to create conceptual clarity and highlight distinctions between approaches in the methods they use and contexts in which they apply.

Research Fellow, Karlsruher Institute of Technology, Germany, marco.binninger@kit.edu

Research Fellow, Karlsruher Institute of Technology, Germany, janosch.dlouhy@kit.edu

Professor, Karlsruher Institute of Technology, Germany, shervin.haghsheno@kit.edu 
Along this line, Frandson et al. (2015) already compared and contrasted Takt Time Planning with the Location-based Management System (LBMS).

In this paper, we detail the approach for collaborative Takt Time Planning of nonrepetitive work which we developed and piloted in the course of delivering a small project.

\section{History OF DESCRIBED APPROACH}

Using the principle of Takt is not new in the German construction industry. Takt was used in incremental launching in the 1970s (Gaillard 1974). Takt Planning was also mentioned in a context of concrete construction by Adolf Schub (1970) in his dissertation "Problems of Takt Planning in Construction Production". These approaches however, only used Takt for the purposes of planning.

The German Lean movement was started by Professor Fritz Gehbauer (2007). The main points of the method are contractual models and cooperative approaches such as the Last Planner System. Further methods and approaches, which are heavily used by consulting companies, were developed based on this. One such approach originates from a project consulted by Porsche Consulting in 2005 and is described in detail in Kaiser's dissertation (Kaiser 2013, p. 68). Kaiser's approach is based on a takted system for operational execution and includes the method Takt Planning and Takt Control. This approach is also mentioned in Friedrich et al. (2013).

The idea of takting work as part of Lean Construction and thereby seeks to create value-creating activities across the entire process chain of equal duration. This idea in combination with a short cycle control of the processes has only been implemented in Germany in the last 10 years. Since then some companies have placed a strong focus on this approach. An example of this is a medium sized enterprise described by Haghsheno et al. (2015). This approach was further developed at KIT (Dlouhy et al. 2016).

\section{GeOgraphicAl AND PROJECT CONTEXT}

The Takt approach described here was developed for building projects with clearly identifiable replicable elements such as hotel construction, and later applied to other types of construction. In the meantime, this approach is applied to all types of buildings from office to residential construction.

The example project in this paper describes the new construction of the fire department of an automobile production plant. In this case takt was used only in the fit-out stage.

The scope of the project has a gross floor area of approx. $500 \mathrm{~m} 2$ for a German automobile producer. To minimize disruption to the fire brigade's state of readiness, the goal was to complete construction as quickly as possible to allow normal operations to resume. Therefore, the original construction sequence with a timeline of 90.5 days (or approx. 18 weeks) was takted.

\section{TheOretical Formulation of TAKT PlanNing AND TAKT CONTROL IN CONSTRUCTION}

\subsection{Takt Time in Manufacturing vs Takt Time in Construction}

The idea of the Lean Construction methods of Takt Planning and Takt Control is to bring the processes necessary for creating value into a uniform flow. As uniformity and $100 \%$ 
consistency can never be achieved in practice, the system is adjusted to the uniform Takt 'beats' given. The more fine-grained a Takt selected, the higher the level of uniformity, and therefore the higher the level of control over the system. For the level of effort needed to control the system the reverse is true. Takt in manufacturing is normally defined in seconds or minutes (Haghsheno et al. 2016)

Kaiser recommends a weekly Takt for the construction sector and justifies this by stating that a Takt under two days in length is very difficult to implement in practice (Kaiser 2013, p. 113). The selected Takt is noticeably dependent on the variability/stability of the system and product, but is not constrained by these. From a Lean perspective, the goal is to reduce the batch size and reduce throughput time.

In practice a weekly Takt is often selected due to the instability of construction processes. Individual examples (Heinonen and Seppänen 2016) of hourly and daily Takt show that the Takt time to be used cannot be seen as a fixed number for all projects. For every project there could be a different takt time.

\subsection{The technical Takt Planning and Takt Control method}

\section{Takt Planning}

The method developed at KIT is based on Kaiser's approach with various points developed in further detail. The Takt Schedule was developed collaboratively by the project team in 12 steps. The steps are shown in figure 1.

In the first step the project was divided into functional working areas. These are sections and areas of a construction which will be carried out using various process sequences. In the second step the priority of different areas was determined from the perspective of the client, and afterwards sorted into the individual areas according to priority. For the selected area (step 3) the Standard Space Unit (SSU) was defined. The SSU is the smallest repetive part in a project. During a workshop the project team planned works to the level of working steps in reverse order.

Step 6 is the most important piece of the method. Quantities were determined for the SSUs and multiplied by a performance factor. In step 7 the working steps were bundled into work packages. This bundling is strongly influenced by the traditional division of works. Step 8 organises the SSUs into practical Takt Areas and allocates the Takt Time. The Takt Time is often determined beforehand according to the needs of the client. The Takt Area is determined according to a calculation. Haghsheno et al. (2016) lists guidelines for the sizing of areas. Harmonization is completed in connection to this. This process levels the work load and is described explicitly by Binninger et al. (2016). The first result in Step 10 is a train of works. Work packages can be bundeled together in one waggon if there is a no collision. Steps 4-10 are then repeated for all Takt Areas. In Step 12 the results are shown in a Takt Plan. 


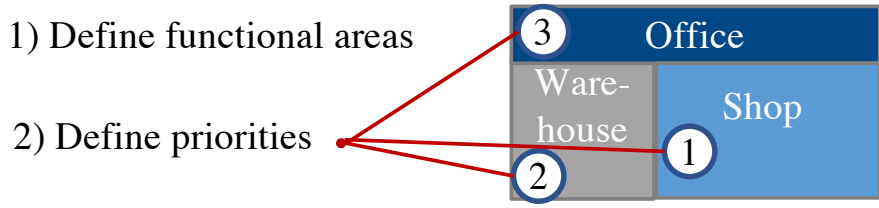

Other functional areas:

Front,

Roof, etc.....

3) Pick one functional area

\section{Office}

4) Define SSU(s) for one functional area

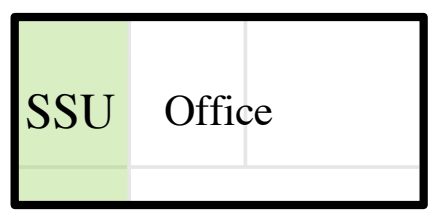

Annotation:

Office with

several levels.

5) Define work packages for every SSU.

\begin{tabular}{|l|l|l|l|l|l|l|l|l|l|l|}
\hline DC1 & HVAC & ELT1 & Paint 1 & DC2 & $\begin{array}{c}\text { Screed f } \\
\text { floor }\end{array}$ & HVAC2 & Paint 2 & ELT 2 & fFlooring & Doors \\
\hline
\end{tabular}

6) Do the calculation of the amount of work for every step.

7) Allocate detailed works steps to work packages. \begin{tabular}{|l|l|}
\hline & Preperation wall \\
- & Door fraiming \\
- & Door blade \\
\hline
\end{tabular}

8) Determine Takt time and Takt area. $\quad \begin{aligned} & \text { Takt area } \\ & \text { e.g. } 1 \text { week }\end{aligned}$

9) Takt levelling:

- shifting variable work steps

- Variation of manpower

- Duplication of wagons

- Buffer

$-\ldots$

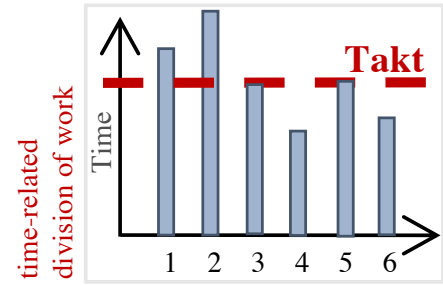

10) Combine the work packages best for determined Takt time and Takt area

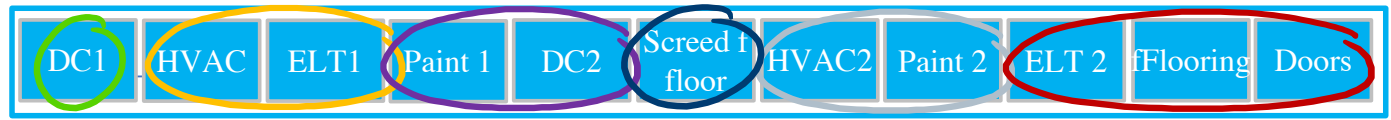

\begin{tabular}{|c|c|c|c|c|c|c|c|}
\hline \multirow{2}{*}{ DC 1 } & ELT 1 & Paint 1 & Screed & Drying & HVAC 2 & ELT 2 \\
\hline & HVAC1 & DC 2 & floor & Ploor \\
\hline
\end{tabular}


11) Do steps 3 to 6 for all functional areas

\begin{tabular}{|l|l|l|l|l|l|l|l|l|l|}
\hline S1 & S2 & S3 & A1 & A2 & A3 & A4 & A5 & A6 & C \\
\hline
\end{tabular}

12) Prepare the takt schedule and determine milestones in order to costumer priority

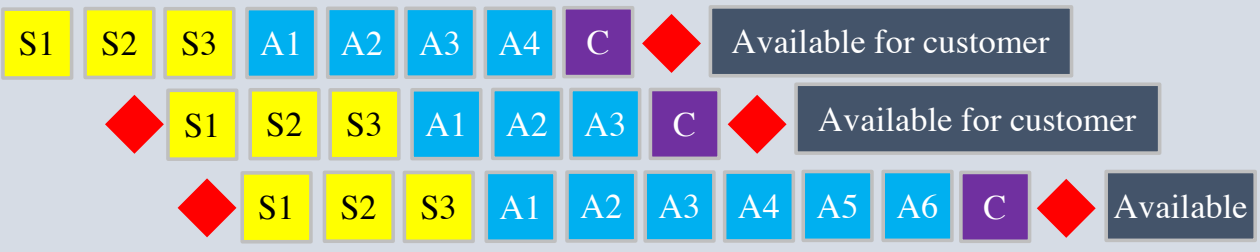

Figure 1: 12 steps of Takt Planning

\section{Takt Control}

Takt Control, also known as "managing the gemba" or "shopfloor management", has the goal of placing control at the place of value creation. Short-cycled (daily) meetings on-site are considered particularly important (Peters 2009). The meetings are moderated by the construction manager, and all persons responsible for execution take part. The site is managed through Takt Control Boards (shopfloor boards). These boards are also standardized, and serve as a medium for visualization to achieve transparency. The key to motivating employees to take part in the meetings is to integrate them in the problemsolving process. The following key points are recorded:

- Number of workers per trade

- Number of machines

- Rate of compliance with the Takt Plan

- Defects in quality

- Safety figures, number of accidents, violations of safety rules

- Number of disruptions to work

- Information on cleanness and tidiness

The key figures and effort values determined according to the Takt Control, can be utilized in the Takt Planning of future projects with little effort.

\subsection{Practical example - Firestation, Dingolfing Bavaria}

During functional analysis (1) the first (Corridor) and ground floors (GF) were defined as separate areas. This is shown in Figure 2. The first floor was prioritized (2).

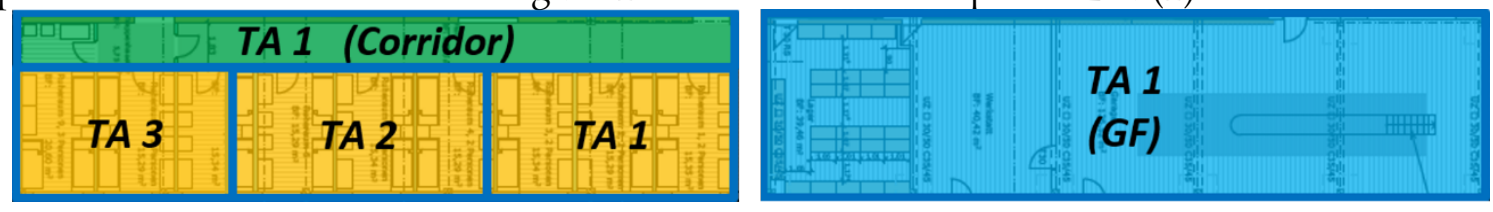

Figure 2: Takt Areas

For the first floor (3) the corridor, bedrooms and ground floor were defined as SSUs (4) before process steps were prepared by the team (5). The works and quantities were 
calculated and multiplied by an effort value (6). An extract of the calculation can be seen below.

\begin{tabular}{|llllll|}
\hline Reference & Trade & Work Content & Quantity & Unit & Waggons \\
\hline Room $\left(15 \mathrm{~m}^{2}\right)$ & DC I & $\begin{array}{l}\text { Place framework, single-sided duplex } \\
\text { planking }\end{array}$ & 25 & $\mathrm{~m}^{2}$ & W1 \\
\hline Room $\left(15 \mathrm{~m}^{2}\right)$ & ELT I & $\begin{array}{l}\text { Installation System } \\
\text { Run cables }\end{array}$ & 3 & $\mathrm{~m}$ & \\
& & Pipe installation & 30 & $\mathrm{~m}$ & $\mathrm{~m}$ \\
Room $\left(15 \mathrm{~m}^{2}\right)$ & Heater I & Prepare heater connection & 12 & $\mathrm{~W} 2$ \\
& & Insulation & 12 & $\mathrm{~m}$ & \\
Room $\left(15 \mathrm{~m}^{2}\right)$ & HVAC I & Ventilation duct & 7 & $\mathrm{~m}$ & \\
\hline
\end{tabular}

Figure 3: Calculation of the work contend

The tasks were assembled into work packages (7). The following figure 4 shows the work packages for the corridor.

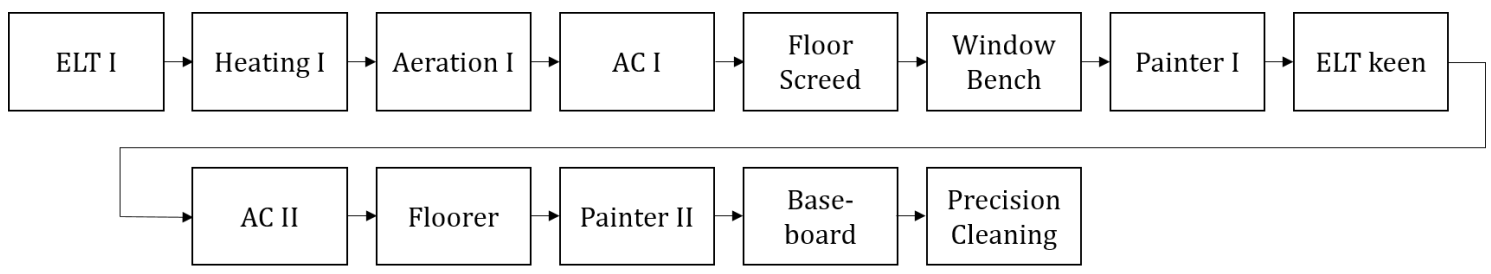

Figure 4: Work packages

After determining the Takt Time and length of the Takt (8) and harmonisation (9) the sequence of the trains was determined (10). In the next step the approach (11) was repeated for the ground floor. In this case study five Takt Areas (3x bedrooms, $1 \mathrm{x}$ corridor, $1 \mathrm{x}$ ground floor) were used. On the first floor a Takt Time of 2.5 days was implemented, while five days was used on the ground floor. Finally, the production timeline was prepared (12) as shown in Figure 5. The result is demonstrated in Figure 6 and 7.

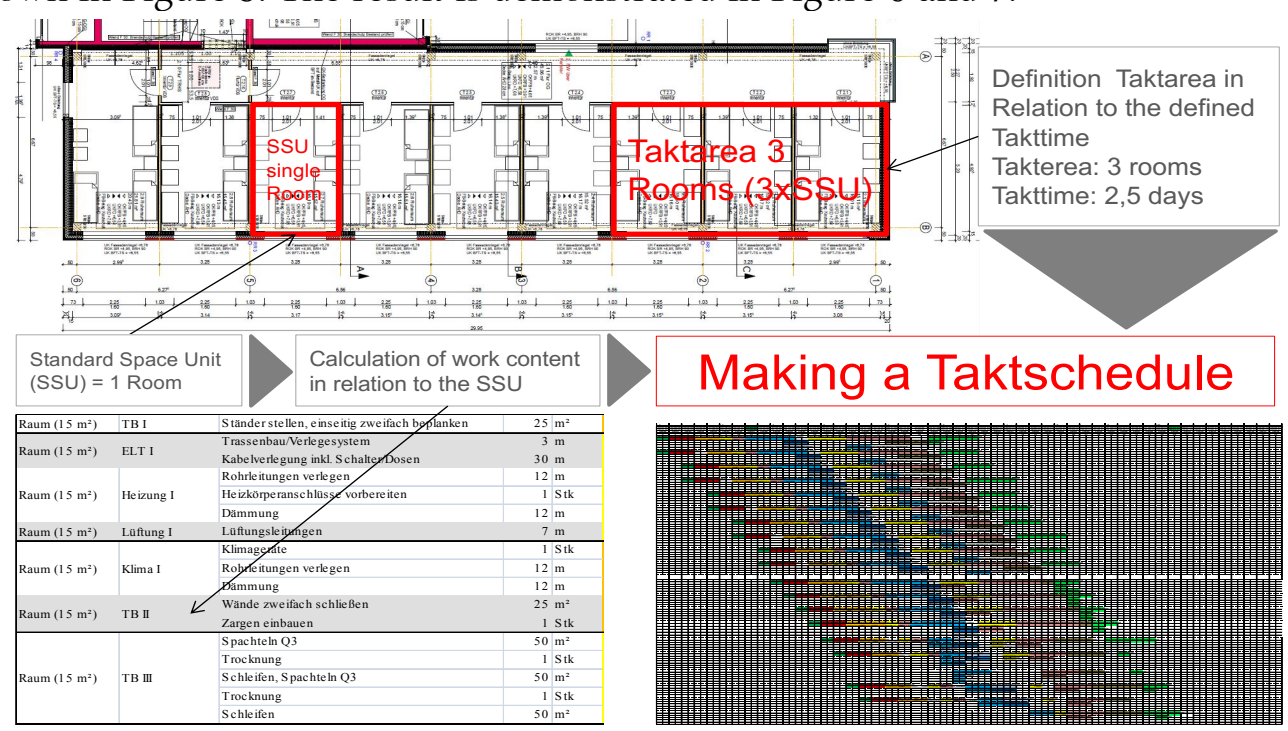

Figure 5: Making a Takt schedule 


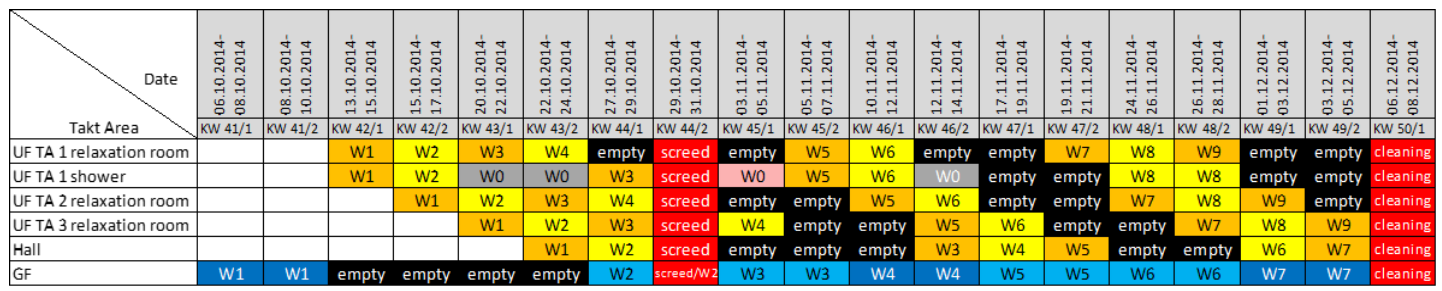

Figure 6: Takt schedule DGF Fire Station (Authored by the Project Team)

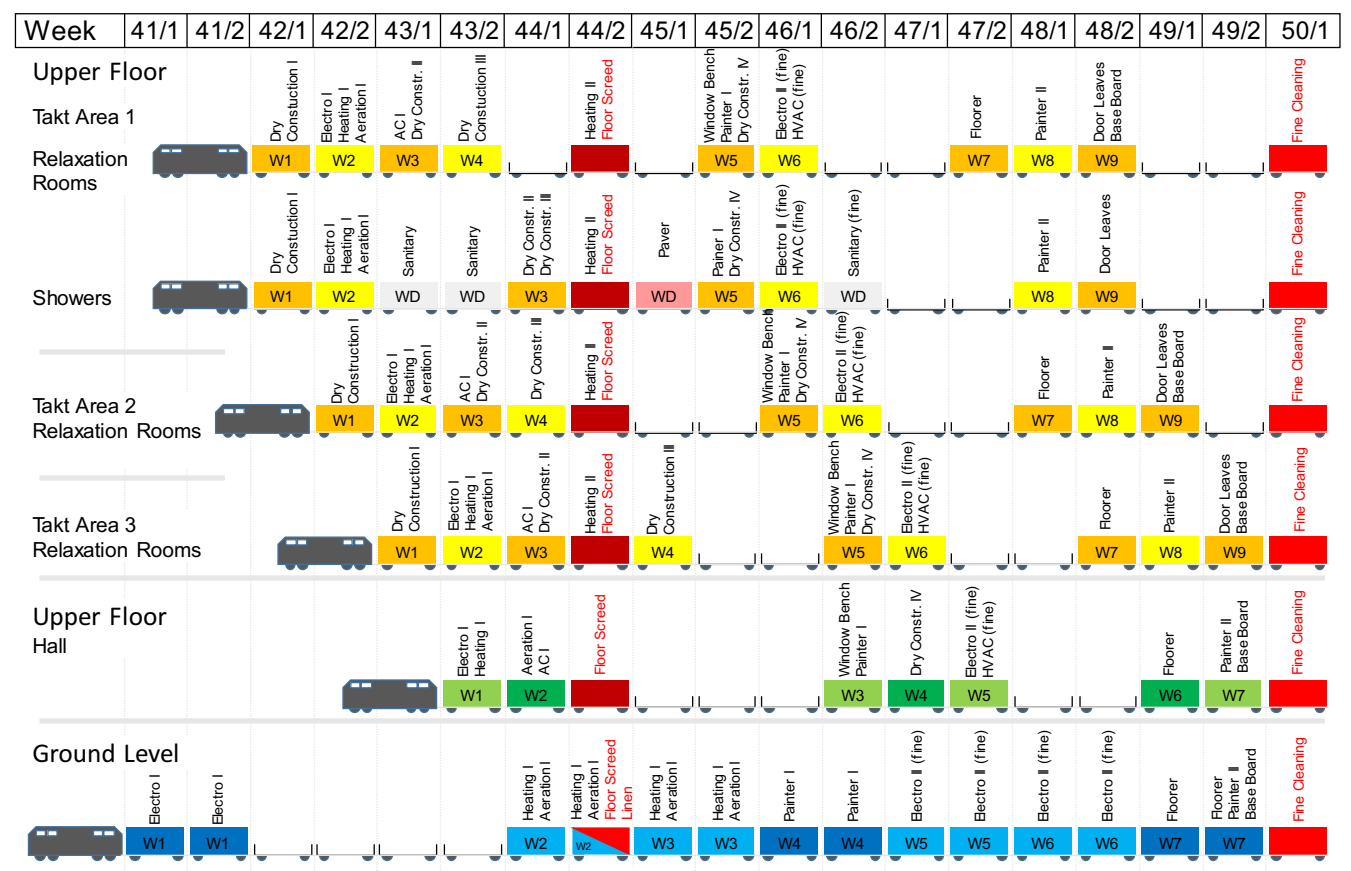

Figure 7: Takt schedule with trains

\section{Takt Time Planning augments the Last Planner System}

The three different layers of a Lean approach to construction are stated in Haghsheno et al. (2015) as follows:

- Production Systems

- Collaborative Systems

- Contract Systems

The authors conclude that a holistic Lean approach must comprise of all three layers. Technical systems such as Takt Systems support transparency and stability by using objective data in a holistic Lean system. Furthermore, the borders of collaborative working could be expanded by using data in democratic production systems. Finally, the focus of technical Takt planning and Takt control is value for the customer while the relationship between Takt Time and Takt Areas define the speed of a project's execution.

\section{ACKNOWLEDGMENTS}

The research as described in this paper was completed as part of the PhD studies of Marco Binninger and Janosch Dlouhy at the Karlsruhe Institute of Technology (KIT). By 
integrating the authors in their Takt projects, the companies weisenburger bau $\mathrm{GmbH}$ and BMW AG made collecting the required data possible.

\section{REFERENCES}

Binninger, M., Dlouhy, J., Oprach, S. and Haghsheno S. (2016): Methods for Production Leveling - Transfer from Lean Production to Lean Contruction. In: Proc. 24th Ann. Conf. of the Int'l. Group for Lean Construction, Boston, MA, USA, sect.6 pp. 53-62.

Dlouhy, J., Binninger, M., Oprach, S. and Haghsheno, S. (2016): Three-level Method of Takt Planning and Takt Control - A New Approach For Designing Production System in Construction. In: Proc. 24th Ann. Conf. of the Int'l. Group for Lean Construction, Boston, MA, USA, sect.2 pp. 13-22.

Frandson, A.G., Seppänen, O., and Tommelein, I.D., (2015): Comparison between location based management and Takt Time Planning. In: Proc. 23rd Ann. Conf. of the Int'l. Group for Lean Construction, 28-31 July, Perth, Australia, pp. 3-12

Friedrich, T.; Meijnen, P.; Schriewersmann, F. (2013): Lean Construction - die Übertragung der Erfolgsmodelle aus der Automobilindustrie (Transformation of successful approaches of the automotive sector). 1. Aufl. Hg. v. Porsche Consulting GmbH: Ernst \& Sohn GmbH \& Co. KG.

Gaillard, H. (1974): Das Takt-Schiebe-Verfahren. TIEFBAU BERUFSGENOSSENSCHAFT, 86(8).

Gehbauer, F. (2007): Was bedeutet Lean Construction? Lean Praxis Tag, 23.01.2007.

Haghsheno, S.; Binninger, M.; Dlouhy, J.; (2015): Wertschöpfungsorientierte Planung und Realisierung von Bauvorhaben durch Lean Construction. Jahresausgabe 2015/1016. III - 13. Hg. v. VDI - Bautechnik.

Haghsheno, S.; Binninger, M.; Dlouhy, J.; Oprach, S. (2016): History and theoretical Foundations of Takt Planning and Takt Control. In: 24th Annual Conference of the International Group for Lean Construction. Boston, USA, 20-22 Jul 2016.

Heinonen, A., and Seppänen, O. (2016): Takt Time Planning: Lessons for Construction Industry from a Cruise Ship Cabin Refurbishment Case Study. In: Proc. 24th Ann. Conf. of the Int'l. Group for Lean Construction, Boston, MA, USA, sect.2 pp. 23-32.

Kaiser, J. \& Zikas, T. (2009): Lean Management im Straßen-und Tiefbau. BauPortal, 121(5).

Kaiser, J. (2013): Lean Process Management in der operativen Bauabwicklung. p. 68

Peters, R. (2009): Shopfloor Management - Führen am Ort der Wertschöpfung (leadership on the shopfloor) LOG_X Verlag, Stuttgart. ISBN 978-3-932298-39-4, S. 27; S.41

Schub, A. (1970): Probleme der Taktplanung in der Bauproduktion (problems of takt planning in construction). Bauverlag

Tommelein, I.D. (2017): Collaborative Takt Time Planning of Non-Repetitive Work. In: Proc. Lean \& Computing in Construction Congress (LC3), Vol. 3 (IGLC), Heraklion, Greece, forthcoming. 